\title{
Favourable Growth Hormone Treatment Response in a Young Boy with Achondroplasia
}

\section{Krstevska-Konstantinova $\mathbf{M}^{*}$, Stamatova A and Gucev $\mathbf{Z}$}

Department of Endocrinology and Genetics, University Pediatric Clinic-Skopje, Macedonia

\begin{abstract}
Background: Achondroplasia is a skeletal dysplasia, being the most common cause of rhizomelic dwarfism.

Case presentation: We present a ten year old boy who was first diagnosed prenatally. He had a mutation C1138G $>$ A in the gene FGFR3 in a heterozygotic constellation. His lgF1 levels and IgFBP3 were normal. Two stimulation tests for growth hormone were performed with normal levels of the hormone. His psychomotor development was adequate for his age except for speech difficulty. He started with recombinant hGH (r-hGH) at the age of 3.4 years in a dose of $0.06 \mathrm{mg} / \mathrm{kg}$. His mean Height SDS (HtSDS) was -2.2 . The growth increased to $10 \mathrm{~cm} /$ year in the first year of therapy (HtSDS-1.1). It decreased during the second year to $4 \mathrm{~cm}$ (HtSDS-1.7) and again increased during the third year to $8 \mathrm{~cm} /$ year (HtSDS-1.3). In the next years the growth was constant $(6.5,2.3,3.5$ $\mathrm{cm} /$ year). He is still growing in the 3rd percentile of the growth curve (HtSDS-1.2). The body disproportion did not aggravate during treatment.
\end{abstract}

Conclusion: The growth was satisfactory in the first 4 years of treatment, although he still continued to grow. The young age at the start of treatment was also of importance. Our other patients with achondroplasia who started treatment older had a poor response to growth hormone.

Keywords: Achondroplasia; Growth hormone treatment; Skeletal dysplasia

\section{Introduction}

Skeletal dysplasias are common causes of severe growth retardation. Among these disorders, achondroplasia is the most common genetic form of chondrodysplasia in humans and is characterized by shortlimb dwarfism, macrocephaly with a prominent forehead, and mid-face hypoplasia [1]. Characteristic radiographic findings of the skeleton such as caudal narrowing of the interpedicular distance, small iliac wing, narrow greater sciatic notch, and metaphyseal flaring of tubular bones are usually observed. Average adult height in achondroplasia is, in the Caucasian population, between 112 and $136 \mathrm{~cm}$ (mean $124 \mathrm{~cm}$ ) for women and $118-145 \mathrm{~cm}$ (mean $132 \mathrm{~cm}$ ) for men [2]. This disorder is inherited as an autosomal dominant trait, although the majority of cases are sporadic. At the last decade of the past century, studies have revealed point mutations in the transmembrane domain of the fibroblast growth factor receptor 3 (FGFR3) gene in achondroplastic heterozygotes and homozygotes [3,4]. The achondroplasia mutation causes increased FGFR3 activity disturbing both proliferation and hypertrophy of the epiphyseal growth plate chondrocytes as well as increasing the pace of osteogenesis $[5,6]$.

Growth hormone $(\mathrm{GH})$ is an important factor for the growth and differentiation of chondrocytes. Trials with GH treatment in achondroplasia have been reported for a long time. Already in 1933, in Denmark, a treatment experiment was done using pituitary extracts in a patient with chondrodystrophy (presumably achondroplasia) [7]. At the past nineties, there have been reports describing the beneficial effects of GH therapy in achondroplasia and hypochondroplasia [810], although patients with achondroplasia are considered to have normal GH secretion. In fact, GH has been widely used to treat non-GH-deficient forms of short stature, such as Turner's syndrome, skeletal dysplasia, intrauterine growth retardation, chronic illness and idiopathic short stature [11-13]. In the study of Bouali and Latrech, a number of treatments for achondroplasia have been compared, including surgical limb lengthening and r-hGH treatment, to future treatments which include the Natriuretic Peptide C-type (CNP) [14].

In the present study, we evaluated the effectiveness of GH administration on the enhancement of longitudinal bone growth in children with achondroplasia.

\section{Case Report}

\section{Materials and methods}

The patient T. M, 10 years old, was diagnosed with achondroplasia prenatally in the 7th month of gestation. His mother had a normal pregnancy, regularly controlled. The height of the mother is $163 \mathrm{~cm}$, and of the father is $172 \mathrm{~cm}$. The patient's only sibling is normal. Birth weight of the patient was $3150 \mathrm{gr}$, his length was $46 \mathrm{~cm}$, with head circumference of 38 $\mathrm{cm}$. He had all the stigmata of the skeletal dysplasia. He was referred to our Endocrinology Department for further follow-up after birth.

His psychomotor development was normal except for speech difficulties. Except the physical features of achondroplasia, he had a various deformity of the knees. Ultrasound of the brain was performed on several occasions, when he was an infant, with normal findings. The Computerized Tomography (CT scan) of the brain did not reveal any abnormalities. His IgF1 levels $(40 \mathrm{mg} / \mathrm{ml})$ and IgFBP3 levels $(1900$ $\mathrm{mg} / \mathrm{ml}$ ) were normal. Two growth hormone stimulation tests were performed at the age of two years, and the values were within normal range. Thyrotropin releasing and thyroid hormone levels were also within normal range. The genetic examination revealed a mutation of C1138G $>A$ in the gene FGFR3 in a heterozygous constellation.

We started growth hormone treatment at the age of three years and four months in a dose of $0.06 \mathrm{mg} / \mathrm{kg}$.

\section{Results}

At start his height was $82.3 \mathrm{~cm}$ and weight was $14 \mathrm{~kg}$ (HtSDS-2.2).

*Corresponding author: Krstevska-Konstantinova M, Department of Endocrinology and Genetics, University Pediatric Clinic-Skopje, Macedonia, Tel: (507) 646-1534; E-mail: mkrstevskakonstantinova@yahoo.com

Received October 16, 2015; Accepted November 29, 2015; Published December 05 2015

Citation: Krstevska-Konstantinova K, Stamatova A, Gucev Z (2015) Favourable Growth Hormone Treatment Response in a Young Boy with Achondroplasia. J Clin Case Rep 5: 660. doi:10.4172/2165-7920.1000660

Copyright: (c) 2015 Krstevska-Konstantinova M, et al. This is an open-access article distributed under the terms of the Creative Commons Attribution License, which permits unrestricted use, distribution, and reproduction in any medium, provided the original author and source are credited. 
Growth increased to $10 \mathrm{~cm} /$ year in the first year of treatment (HtSDS-1.1). It decreased during the second year to four $\mathrm{cm} /$ year (HtSDS-1.7) and again increased during the third year to eight $\mathrm{cm} /$ year (HtSDS-1.3). In the next years the growth was constant $(6.5 \mathrm{~cm} ; 2.3 \mathrm{~cm}$; $3.5 \mathrm{~cm} /$ year). At the age of 10 , he is still growing in the third percentile of the normal growth curve (HtSDS-1.2). The body disproportion did not aggravate during treatment.

\section{Discussion}

r-hGH administration studies in achondroplasia have been limited, as it was thought initially that GH therapy would not be helpful, given that patients usually do not manifest a hormone deficiency. However, encouraging short-term results of $\mathrm{GH}$ treatment in achondroplasia have been reported. Although differing age groups, treatment periods, and dosages make comparison between studies difficult, it can be speculated that higher GH doses and younger age of initiation of treatment result in better growth response. Stamoyannou et al. [15] studied fifteen children with achondroplasia (seven boys 4.8-12.2 years of age and twelve girls 5.7-12.2 years of age). The patients were treated daily hGH at a dosage of $1 \mathrm{IU} / \mathrm{kg} /$ week. The authors of the study concluded that, hGH treatment resulted in an increased growth rate in some children with achondroplasia, however the increase waned during the second year of treatment, which was not the case in our study. Tanaka et al [1] treated forty two children (16 males and 26 females) with achondroplasia with GH for more than 2 years. GH was administered at a dose of $0.5 \mathrm{IU} / \mathrm{kg} /$ week or $1 \mathrm{IU} / \mathrm{kg} /$ week for at least 2 years. The conclusion of this study was that GH might be beneficial in the treatment of short stature in children with achondroplasia in the first two years of treatment, in accordance to our study. Ramaswami et al., [16] described the effects of GH therapy for up to 6 years on stature and body proportions of 35 children with achondroplasia. GH was administered at a median (range) dose of $30(15.8-40) \mathrm{U} / \mathrm{m}^{2}$ per week. Treatment caused a significant increase in HtSDS year to year until year 4 , that was subsequently sustained with no significant further change (year 5 and 6 versus year 4). Age, as in our study, was the most important variable accounting for the first-year response in HtSDS and dose of $\mathrm{r}-\mathrm{hGH}$ did not influence this. The conclusion was that a young age at initiation of therapy prevented the characteristic Ht deficit from accumulating. The greater increase in spinal Ht accentuated the existing disproportion. The addition of later surgical leg lengthening could offer the possibility of proportionate adult stature just within the normal range. Hertel et al., [17] studied 35 achondroplastic children who received a dosage of either $0.1 \mathrm{IU} / \mathrm{kg} /$ day or $0.2 \mathrm{IU} / \mathrm{kg} /$ day. $\mathrm{GH}$ treatment was interrupted for 12 months after 2 years of treatment in prepubertal patients to study catch-up growth. Mean growth velocity (baseline $4.5 / 4.6 \mathrm{~cm} /$ year for the groups) increased significantly by $1.9 / 3.6 \mathrm{~cm} /$ year during the first year and by $0.5 / 1.5 \mathrm{~cm} /$ year during the second year. These authors concluded that GH treatment in children with achondroplasia improves height during four years of therapy without adverse effect on trunk-leg disproportion, which data proved to be the same in our case.

The data from our case report demonstrated that GH treatment in a prepubertal achondroplastic child increased his growth by $10 \mathrm{~cm} /$ year in the first year of follow up. It decreased during the second year to four $\mathrm{cm}$ /year (HtSDS-1.7) and again increased during the third year to eight $\mathrm{cm} /$ year (HtSDS-1.3). In the next years the growth was constant $(6.5$ $\mathrm{cm} ; 2.3 \mathrm{~cm} ; 3.5 \mathrm{~cm} /$ year). At the age of 10 , the treatment still continues, because he is growing in the third percentile of the normal growth curve (HtSDS-1.2) and he has not yet reached his final height.

\section{Conclusion}

The growth was satisfactory in the first four years of treatment, although the patient still continued to grow. His young age at start of the treatment was also of importance, which is the conclusion of other authors who performed similar studies. Also we had a longer period of favorable growth. Our other patients with achondroplasia who started treatment at an older age had a poor response to $\mathrm{GH}$ treatment.

\section{References}

1. Tanaka H, Kubo T, Yamate T, Ono T, Kanzaki S, et al. (1998) Effect of growth hormone therapy in children with achondroplasia: growth pattern, hypothalamicpituitary function, and genotype. Eur J Endocrinol 138: 275-280.

2. Horton WA, Rotter JI, Rimoin DL, Scott Cl, Hall JG (1978) Standard growth curves for achondroplasia. J Pediatr 93: 435-438.

3. Shiang R, Thompson LM, Zhu YZ, Church DM, Fielder TJ, et al. (1994) Mutations in the transmembrane domain of FGFR3 cause the most common genetic form of dwarfism, achondroplasia. Cell 78: 335-342.

4. Rousseau F, Bonaventure J, Legeai-Mallet L, Pelet A, Rozet JM, et al (1994) Mutations in the gene encoding fibroblast growth factor receptor-3 in achondroplasia. Nature 371: 252-254

5. Wang Q, Green RP, Zhao G, Ornitz DM (2001) Differential regulation of endochondral bone growth and joint development by FGFR1 and FGFR3 tyrosine kinase domains. Development 128: 3867-3876.

6. Ornitz DM, Marie PJ (2002) FGF signaling pathways in endochondral and intramembranous bone development and human genetic disease. Genes Dev 16: $1446-1465$.

7. Mørch ET (1941) Chondrodystrophic dwarfs in Denmark, Copenhagen: Munksgaard. /researchgate/

8. Nishi Y, Kajiyama M, Miyagawa S, Fujiwara M, Hamamoto K (1993) Growth hormone therapy in achondroplasia. Acta Endocrinol (Copenh) 128: 394-396.

9. Horton WA, Hecht JT, Hood OJ, Marshall RN, Moore WV, et al. (1992) Growth hormone therapy in achondroplasia. Am J Med Genet 42: 667-670.

10. Appan S, Laurent S, Chapman M, Hindmarsh PC, Brook CG (1990) Growth and growth hormone therapy in hypochondroplasia. Acta Paediatr Scand 79 : 796-803.

11. Hindmarsh PC, Bridges NA, Brook CG (1991) Wider indications for treatment with biosynthetic human growth hormone in children. Clin Endocrinol (Oxf) 34: 417-427.

12. Genentech Collaborative Study Group (1989) Idiopathic short stature: results of a one-year controlled study of human growth hormone treatment. Journal of Pediatrics 115: 713-719.

13. Chatelain P, Job JC Blanchard J, Ducret JP, Oliver M (1994) Dose-dependant catch-up growth after 2 years of growth hormone treatment in intrauterine growth-retarded children. Journal of Clinical Endocrinology and Metabolism 78: 1454-1460.

14. Bouali H, Latrech H (2015) Achondroplasia: Current Options and Future Perspective. Pediatr Endocrinol Rev 12: 388-395.

15. Stamoyannou L, Karachaliou F, Neou P, Papataxiarchou K, Pistevos G, et al. (1997) Growth and growth hormone therapy in children with achondroplasia: a two-year experience. Am J Med Genet 72: 71-76.

16. Ramaswami U, Rumsby G, Spoudeas HA, Hindmarsh PC, Brook CG (1999) Treatment of achondroplasia with growth hormone: six years of experience. Pediatr Res 46: 435-439.

17. Hertel NT, Eklöf O, Ivarsson S, Aronson S, Westphal O, et al. (2005) Growth hormone treatment in 35 prepubertal children with achondroplasia: a five-year dose-response trial. Acta Paediatr 94: 1402-1410. 